\title{
Jacek Bylica, Cygańska rapsodia. Transkulturowe studium rzeczywistości społecznej andrychowskich Romów - konteksty pedagogiczne, Wydawnictwo Uniwersytetu Jagiellońskiego, Kraków 2019, ss. 238
}

Kultura stanowiła i stanowi czynnik różnicujący, może zamykać tożsamościowo lub otwierać na Innych i ich kultury. Jednak ten proces zawsze dzieje się w określonych warunkach społecznych, kulturowych, ekonomicznych, politycznych. W zależności od warunków licznych okoliczności każda grupa narodowościowa, etniczna czy religijno-wyznaniowa poszukuje sposobów zachowania odziedziczonych wartości i jednocześnie korzystnej pozycji w strukturach, w określonej stratyfikacji społecznej, a tym samym czerpania i korzystania z różnych zasobów innych grup. Tak więc zjawisko transkulturowości miało miejsce od zarania dziejów, na co zwraca uwagę Jacek Bylica, przedstawiając liczne meandry transkulturowości (s. 16-20). Przywołuje także stanowisko Doroty Misiejuk zaprezentowane w „Pograniczu. Studia Społeczne” nr 25 z 2011 roku, w artykule Strategia transkulturowości w edukacji. Perspektywa artefaktu kulturowego, która konstatuje, że transkulturowość istnieje naturalnie w ludzkich zbiorowościach pograniczy od zawsze. To, że treści innych kultur stają się treściami naszej kultury, że ma miejsce wzajemne ubogacanie się, stapianie, użyźnianie, mozaikowość, hybrydyzacja, restrukturyzacja, dekulturacja i wiele innych form, wydaje się zachodzić ustawicznie i mamy na to niewielki wpływ. Problemem było i jest to, w jakim zakresie i stopniu odmienne grupy - różniące się od nas - były zauważane, uznawane i szanowane. Lub odwrotnie - dlaczego tak się działo i jakie okoliczności temu towarzyszyły?

1 Jerzy Nikitorowicz, Wydział Nauk o Edukacji, Uniwersytet w Białymstoku, Polska, e-mail: j.nikitorowicz@uwb.edu.pl, ORCID ID: https://orcid.org/0000-0003-4371-8322. 
Historycy, analizując na przykład funkcjonowanie I Rzeczypospolitej, wskazują na trwający kilka wieków eksperyment wielokulturowy, co można porównać do obecnej sytuacji w wielu krajach Europy Zachodniej i sformułować pytania o czasokresy, liczne uwarunkowania, o to, jak długo i na jakich warunkach społeczeństwa przyjmujące w wiekach poprzednich i współcześnie chciały prowadzić dialog z przybyszami, czy idea, zasady i polityka wielokulturowości były realizowane z uznaniem i poszanowaniem ich odmienności, jakie były zasady, metody i formy jej prowadzenia i jakie mogłyby być obecnie skuteczne. Szczególnie istotne wydaje się poczucie zagrożenia, to, czy i jaki był dotychczasowy dialogiczny i wspólnotowy wymiar ukształtowanych więzi oraz czy nie zostanie zdewaluowany lub zdewastowany. W I Rzeczpospolitej przybysze należący do innych grup etnicznych czy wyznaniowych nie stanowili zagrożenia, nie obawiano się zdominowania, zagrożeń dla stanu rządzącego. Istotne było to, czy byli przydatni państwu i jego mieszkańcom. „Żydzi byli przydatni z uwagi na swe obeznanie z handlem i operacjami finansowymi, podobnie Karaimi i Ormianie. W przypadku Tatarów, częściowo też Karaimów, decydowały względy militarne, w przypadku Niemców ich kompetencje gospodarcze. Podobnie było w epoce wczsnonowożytnej: mennonici mieli niekwestionowane kompetencje w zakresie melioracji, Włosi - w zakresie gospodarki, dyplomacji i oczywiście kultury artystycznej, Szkoci dysponowali kompetencjami militarnymi i dodatkowo wypełniali lukę w zakresie handlu wewnętrznego” (Kopczyński, 2010, s. 19-20).

Michał Kopczyński zwraca uwagę, że tam, gdzie wyczuwano zagrożenie, szlachta potrafiła się bronić. Przykładem może być odebranie królowi w 1576 roku prawa do nobilitacji i nadawania indygenatu (obywatelstwa - szlachectwa) i przekazanie tych praw sejmowi. We wstępie do pracy Pod wspólnym niebem. Narody Dawnej Rzeczypospolitej Kopczyński pisze o Rzeczypospolitej Obojga Narodów jako państwie bez stosów. Podkreśla panującą w niej tolerancję religijną, która była w XVI wieku ewenementem na skalę europejską. Szczególną wartością pracy w kontekście edukacji międzykulturowej jest analiza trzech grup narodów: miejscowych - zasiedziałych, „wmieszkanych”, czyli imigrantów przybywających na ziemie Rzeczpospolitej już w średniowieczu, jeszcze zanim państwo objęło swoimi granicami Litwę i Ruś (Niemcy, Żydzi, Tatarzy, Ormianie, Cyganie, Karaimi), oraz „przybyszy”, czyli cudzoziemców napływających w wieku XVI i XVII w poszukiwaniu lepszych warunków życia (Szkoci, Włosi, holenderscy mennonici) (Kopczyński, 2010, s. 7-8).

Należałoby w kontekście powyższego zapytać, jak Romowie „wmieszkiwali się”, czy i w czym byli przydatni, jak byli postrzegani, jak funkcjonowali i realizowali się, w jakie relacje z innymi wchodzili itp. W tym bowiem upatruję 
porozumienie i wymianę kulturową, komunikację i nabywanie kompetencji międzykulturowych niezbędnych do rozwoju zróżnicowanego kulturowo społeczeństwa i niwelowania powstających na tym tle konfliktów. Czy w pracy Jacka Bylicy znajdziemy odpowiedź na powyższe problemy i wskazania dla teorii i praktyki pedagogicznej?

Chciałbym w pierwszej kolejności zwrócić uwagę, że Cyganie (Romowie) „wmieszkali” się w ziemie Rzeczpospolitej, nigdy nie posiadając własnego państwa. Jacek Bylica zwraca uwagę, że Romowie pochodząc z Indii, odziedziczyli bogate zasoby duchowo-kulturowe, a ich flaga w swej symbolice nawiązuje do flagi Indii. Nie postrzegają jednak Indii jako swojej ojczyzny, co rzeczywiście można uznać za istotny wskaźnik transkulturowości rozumianej jako wyjście poza, bycie za granicą. Jednak nie ten wskaźnik bierze pod uwagę Autor książki o andrychowskich Romach. Kierując się intuicją, czuciem, co uznaje za zasadnicze komponenty romskiego świata, przyjmuje, że „romski świat charakteryzuje umiejętność przenikania - przenikania rzeczywistości oraz innych ludzi. [...] Przenikanie zaś ściśle koresponduje z ideą transkulturowości, która może być rozumiana jako zdolność przenikania (się) poszczególnych kultur” (s. 9).

Przenikanie Jacek Bylica łączy więc z ideą transkulturowości, a tę ideę ze zdolnością przenikania się kultur, a także rozwiązywania konfliktów między nimi. Przyjmuje także, że Romowie „mogą stać się naturalnymi pionierami transkulturowości” (Bylica, 2019, s. 9). Jeżeli pierwsze założenie rozumiem, to drugie już nie. Uważam, że Romowie byli w historii takimi pionierami i nie sądzę, aby obecnie mogli się nimi stać... Uważam, że obecnie można, analizując przeszłość, ukazać, jak się adaptowali, jak przebiegał proces akulturacji, czy i w jakim zakresie kultywowali i kultywują wartości i normy swojej kultury, jak byli włączani w proces edukacji międzykulturowej, jakie konflikty powstawały i na jakim tle, jak były rozwiązywane, czy i w jakich wymiarach nastąpiła i następuje asymilacja, w jakich była „wymuszana”, w jakich dobrowolna, w jakim zakresie przyczynili się do kształtowania kultury pogranicza itp.

Autor Cygańskiej rapsodii jednak nie formułuje takich problemów. Stwierdza (s. 110): „Główny problem badawczy sformułowano w formie pytania: jak przedstawia się obraz transkulturowej rzeczywistości społecznej andrychowskich Romów”. Nie formułuje problemów szczegółowych i nie rozumiem, jaki jest sens określania powyższego problemu głównym. Nie to jednak jest istotne, a założenie, że ten obraz już jest transkulturowy, że Romowie już się stali „pionierami transkul- 
turowości”. Można więc uznać, że w dzisiejszym wielokulturowym, zmiennym, dynamicznym, nieprzewidywalnym świecie wszystko jest możliwe, każde założenie. Sądzę, że kategoria rapsodii, pieśni ludowej czy narodowej, wynikającej z wewnętrznej potrzeby i duchowości, pieśni nieschematycznej, tworzonej z potrzeby chwili i sytuacji w nomadycznym życiu, bez specjalnej struktury, mogła dobrze oddawać kształtowanie się rzeczywistości społecznej Romów w przeszłości, ale nie obecnie. Romom w połowie lat sześćdziesiątych poprzedniego wieku zablokowano bowiem życie taborowe. Nie rozumiem, dlaczego Autor Cygańskiej rapsodii jako pełnomocnik burmistrza ds. mniejszości narodowych i etnicznych, jako aktywny i twórczy mieszkaniec miasta Andrychowa, przyjął i starał się czynić wszystko, aby interpretować rzeczywistość społeczną andrychowskich Romów w kontekście idei transkuturowości. Uznał, że tak jest i Jego studium jest transkuturowe, badania transkulturowe, praca transkuturowa itp.

Autor założył, że Romowie mogą stać się transkulturowymi pionierami, jednak nie rozumiem, dlaczego nie wyszedł z mniej dyskusyjnego założenia, że żyjemy w warunkach wielokulturowości, że mamy taki stan empiryczny. Wobec powyższego podejmuje próbę ukazania, jak w tych warunkach wielokulturowości Romowie andrychowscy wpisują się w ideę czy koncepcję transkulturowości, są przykładem grupy etnicznej, która według tych zasad kształtuje rzeczywistość społeczną. Używanie pojęcia „transkulturowość” w różnych ujęciach często odbierałem jak grę słów. To za mało, aby przekonać czytelnika, że mamy do czynienia z transkulturowym studium rzeczywistości społecznej andrychowskich Romów. Nie mogę przyjąć zapewnienia Autora, że całość projektu badawczego tworzy solidny, pedagogiczny „gmach transkulturowy”.

Jeżeli przyjmiemy, że kulturą jest to wszystko, co nie jest naturą, to możemy uznać każde rozumienie „trans”, które Autor przedstawia w analizowanej pracy. Trudno byłoby odnaleźć coś, co nie jest wychodzeniem poza granice kulturowe. Stąd Bylica wskazuje na transkulturowy świat, ideę transkulturowości, transkulturowy paradygmat, tożsamość transkulturową, orbitę i edukację transkulturową, także na edukację transkulturową zrównoważonego rozwoju i wychowanie transkulturowego człowieka itp. Na s. 49 zauważa: „W pedagogice, oprócz innych zaprezentowanych w niniejszym rozdziale znaczeń, prefiks »trans « oddawałby również "pedagogiczny trans «, a więc działanie pełne zaangażowania i pasji, związane z wychowaniem transkulturowego człowieka. W tym kontekście można mówić o »transpedagogice «”. Można, ale czy jest taka potrzeba i sens. Dlaczego nie mówić o „inter” - między, wśród, współ. Na s. 53 Autor podkreśla, „iż rzeczywistość społeczna jest fenomenem konstruowanym w procesie interakcji”, a więc bardziej „inter” niż „trans”. Stąd, zapoznając się z pracą, zastanawiałem się, co ten 
prefiks „trans” miałby zmienić, co tłumaczyć, czy i jakie nowe znaczenie zostało mu nadane, czym się Autor kieruje, rewitalizując to pojęcie, znane i zachodzące od wieków, po cóż transpedagogika - czy kategoria interdyscyplinarności nie wystarcza, czy rzeczywiście jest potrzeba wskazywania na „nową formę humanizmu”, jaką stanowi, zdaniem Autora, transkulturowość, jak traktować chociażby takie zdanie (s. 48): „[...] za przedmiot pedagogiki transkulturowej uznać należy wychowanie w warunkach transkulturowości, w którym główną rolę odgrywa edukacja transkuturowa”.

Struktura książki jest jasna, a treści zaprezentowane ciekawe poznawczo i inspirujące do analiz, porównań, refleksji, do wyrażania odmiennego zdania, szczególnie wobec przyjętej koncepcji transkulturowości. Praca składa się z wprowadzenia, czterech części, dyskusji wyników oraz wniosków z badań, zakończenia, załączników, bibliografii, spisu cykli i diagramów. W części pierwszej, zatytułowanej Transkulturowy paradygmat badań naukowych, Autor przedstawia koncepcję transkulturowości oraz stan jej aplikacji w naukach humanistycznych, społecznych oraz medycznych. Ukazuje dylematy, z jakimi mierzy się transkulturowość, nakreśla charakterystykę badań pedagogicznych lokowanych w tej perspektywie teoretycznej. Odwołując się ustawicznie do Wolfganga Welscha, wskazuje na zjawisko przenikania się treści kulturowych, dyscyplin naukowych, różnych dróg poznania, orientacji metodologicznych.

Poczynając od wprowadzenia, Bylica przyjmuje, że funkcjonujemy w transkulturowym świecie i idea transkulturowości najpełniej oddaje mentalność romską. Uważam, że funkcjonujemy w warunkach wielokulturowości, w wielokulturowym świecie i ukierunkowujemy się wszyscy, mniej lub bardziej świadomie, ku wychodzeniu na pogranicza kultur, aby bardziej zrozumieć siebie i innych. Tak też dzieje się w nauce, która jest wieloparagmatyczną, zorientowaną na wartości pluralizmu, interdyscyplinarną, stąd część pierwsza pracy nosi tytuł Transkulturowy paradygmat badań naukowych. Zgadzam się w pełni z potrzebą wychodzenia poza dyscyplinę, wieloparagmatyczność, współistnienie i dialog różnych paradygmatów, ujęcia wielodyscyplinarne. To jest jasne, znane i nie traktowałbym przedstawionego w tej części transkulturowego paradygmatu badań naukowych jako nowego paradygmatu. Autor pisze o podróży w nieznane, aby dotrzeć do pełnego i skrystalizowanego obrazu transkulturowej jakości, nie zauważając, że od kilku dziesięcioleci podejmowana jest ta problematyka. Nie odwołuje się do żadnej pracy Lecha Witkowskiego (na przykład Uniwersalizm pogranicza, Ku pedagogii 
pogranicza, W stronę edukacji (dla) pogranicza, Rozwój i tożsamość w cyklu życia, Tożsamość i zmiana). Między innymi te prace pozwoliły mi już na początku lat 90. poprzedniego stulecia podjąć próbę określenia istoty i fenomenu pogranicza, kształtowania się tożsamości na pograniczu kultur i w tym kontekście wskazania na wyzwania i zadania edukacji międzykulturowej (Nikitorowicz, 1995). Zdolność i umiejętność przenikania się poszczególnych kultur, która zdaniem Bylicy koresponduje z ideą transkulturowości, Witkowski traktuje jako tzw. efekt pogranicza, tj. wzbogacania jednostkowych lub grupowych tożsamości poprzez interakcje z innymi, bez odruchu okopywania się, izolowania odrębności na ekskluzywne i wrogie sobie obozy: „Nie jest przypadkiem, że w wizjach nowoczesnych społeczeństw przebija się idea demokracji jako celebrowania różnicy, jako stylu dopuszczania do głosu inności - także mniejszości - na prawach nie uwikłanych w degradację” (Witkowski, 1995, s. 13). Czy przybliżona przez Witkowskiego idea Michała Bachtina, idea „otwarcia ku pograniczu” przestała mieć rację bytu i odeszła już do niebytu, dlaczego Bylica nie dokonuje analiz i interpretacji pogranicza - obok terytorialnego (stykowego i przejściowego) treściowego, interakcyjnego i osobowego - jako stanów i aktów świadomości jednostek wychodzących na pogranicza myślowe, dlaczego nie wydobywa z tych koncepcji elementów użytecznych dla zaprojektowania badań własnych, nie poddaje analizie i krytycznej ocenie w kontekście przydatności do własnego projektu badawczego?

W części drugiej noszącej tytuł Transkulturowa rzeczywistość społeczna Romów Autor podejmuje próbę przedstawienia specyfiki kulturowej Romów. Przedstawia stan badań dotyczących rzeczywistości społecznej Romów w Małopolsce i w ten sposób przybliża głównych bohaterów badań. Część trzecia jest konsekwencją poprzedniej i dotyczy metodologii badań terenowych. Jest to poprawna prezentacja koncepcji badawczej oraz zastosowanej metodologii badań jakościowych. Zgadzam się z Autorem, że romski świat może charakteryzować się umiejętnością przenikania, w którym może zawierać się klucz do rozumienia istoty współczesnego świata, ale nie określiłbym tego transkulturowym przenikaniem. „Trans” był i jest rozumiany oraz interpretowany jako wyjście poza, przekroczenie kultury odziedziczonej, bycie za granicą, z drugiej strony, po drugiej stronie miedzy, która dzieli pewne obszary czy przestrzenie. Jednak Bylica twierdzi, że jedną z konsekwencji przyjęcia perspektywy transkulturowej jest dewaluacja tradycyjnej autonomii „swój-obcy”, Na jej miejscu pojawia się kategoria bliskości (s. 19). Skąd takie pobożne życzenie. Pojawienie się tej kategorii może być wynikiem wielu działań edukacyjnych, poczynając od przedszkola, efektem aktywnego uczestnictwa w programach uwrażliwiania na odmienność kulturową. W jednym miejscu (s. 16) wskazuje, że transkulturowość traktuje jako etap rozwoju idei 
wielo- i międzykulturowości, w drugim natomiast (s. 20) pisze o transkulturowości formułowanej w opozycji do koncepcji wielo- i międzykulturowości.

Powyższa narracja nie przekonuje mnie w kontekście dorobku naukowego, badań i analiz z zakresu edukacji międzykulturowej. Możemy i powinniśmy korzystać z takiej czy innej perspektywy, podejmując i realizując badania, jednak nie można nie zauważać innych perspektyw i przyjąć pewnej perspektywy jako wiodącej, bez polemiki, bez krytycznej ananlizy. Gdyby dokonać szczegółowej analizy i interpretacji teorii akulturacji w ujęciu antropologii amerykańskiej i europejskiej, przedstawić fazy - etapy akulturacji, warunki i okoliczności jej zachodzenia, zauważyć akulturację symetryczną i niesymetryczną, moim zdaniem przedstawiony obraz andrychowskiej mniejszości romskiej byłby bardziej czytelny i przekonujący. Uważam, że przyjęcie koncepcji transkuturowości, wskazywanie na nią jako coś nowego doprowadziło do jej nadinterpretacji.

W powołanej w 1994 roku, z inicjatywy Tadeusza Lewowickiego, Federacji Społecznych Zespołów Badań Kultury i Oświaty Pogranicza wskazywaliśmy i charakteryzowaliśmy warunki wielokulturowości, w których żyjemy, i określaliśmy potrzebę prowadzenia edukacji międzykulturowej, aby wdrażać do zauważania odmienności, poznawać ją, doświadczać, starać się rozumieć, współpracować itp. W efekcie kształtowaliśmy kulturę pogranicza, która charakteryzuje się właśnie przenikaniem treści, ustawicznymi interakcjami, świadomością porozumienia i zrozumienia, wartością ustawicznego dialogu wewnętrznego i zewnętrznego. Wskazywaliśmy, że funkcjonując w warunkach wielokulturowości, w pierwszej kolejności istotne jest poznanie siebie, uświadomienie wartości i znaczenia własnej kultury, aby można było prowadzić dialog z innymi, określać zasady współpracy, kształtować zasady i postawy tolerancji itp. Uważam, że problemem nie jest wyjście poza, przekroczenie granic swojej kultury, a świadomość, że człowiek nie może być zakładnikiem kultury odziedziczonej, która jest jednak bazą/podstawą jego rozwoju, której nie jest w stanie się wyzbyć. Stąd problemem z pedagogicznego punktu widzenia jest przepracowanie wartości kultur, w których uczestniczymy bezpośrednio i pośrednio, analiza obiektywnej i subiektywnej potrzeby lub konieczności uczestniczenia w nich, uświadomienia ich granic i potrzeby wychodzenia poza nie, aby wracać bogatszym kulturowo, rozumieć i szanować różnice, nabyć umiejętność dialogowania i negocjowania, promowania pokojowych rozwiązań.

W kontekście powyższego nie mogę zgodzić się z takim stwierdzeniem „Transkulturowość stanowi odpowiedź na dominujące dotychczas koncepcje wielo- i międzykulturowości, które aktualnie rozumiane są jako nazbyt statyczne, a przede wszystkim niewyjaśniające w sposób adekwatny współczesnych feno- 
menów kulturowych” (s. 16). Uważam, że Autor myli ideę wielokulturowości, politykę wielokulturowości ze stanem wielokulturowości - faktem empirycznym, nie zauważając, że edukacja międzykulturowa wielokulturowości nie traktuje jako ideologii, a analizuje ją jako zjawisko, fakt empiryczny, zjawisko współwystępowania na tej samej przestrzeni grup o odmiennych kulturowych cechach, ale przede wszystkim jako zjawisko tożsamościowe i edukacyjne, pozwalające analizować etos tożsamościowy grup, który winien być poznawany i kultywowany, a w efekcie prezentowany jako tzw. efekt pogranicza czy efekt kultury pogranicza. Faktem jest, na co zwracałem niejednokrotnie uwagę, że idea wielokulturowości nie sprawdziła się w krajach Europy Zachodniej. Prowadzoną politykę wielokulturowości z zasadami poprawności politycznej i relatywizmu kulturowego spotkały niepowodzenia, co powoduje nowe wyzwania i konieczność podjęcia intensywniejszej pracy z zakresu edukacji międzykulturowej. Dlatego edukacja międzykulturowa proponuje bogactwo praktyk edukacyjnych i społecznych o różnym charakterze na poziomie lokalnym, regionalnym, narodowym, międzynarodowym, praktyk polegających na uwzględnieniu w działaniach potrzeb, oczekiwań, aspiracji, prawa do zachowania własnej kultury i kreowania zasad współżycia i współodpowiedzialności za określoną przestrzeń życia społecznego.

Trudno jest mi przyjąć traktowanie transkulturowości jako etapu rozwoju idei wielo- i międzykulturowej. Przekraczanie i wychodzenie poza granice było i jest immanentnie zawarte w międzykulturowości, w idei pogranicza kultur czy w procesie kształtowania człowieka pogranicza kultur, jako naturalna, odwieczna ciekawość człowieka poznającego to, co jest poza granicą, poza tym, co już poznał, doświadczył, co wie i widzi. Nie jestem w stanie uznać, że ten nowy paradygmat, jak go określa Bylica, jest odpowiedzią na kryzys i potrzeby społeczne. Jak wskazywałem wyżej nie jest ani nowy, ani nie stanowi, jak wskazuje Autor pracy, etapu w procesie dialogu kultur. Stąd za istotne uważam działania edukacyjne w zakresie rewitalizacji heterologii i paradygmatu współistnienia kultur, wymiany i ustawicznego dialogu wewnętrznego i zewnętrznego, świadomego przekraczania granic własnej kultury, aby bardziej się rozumieć i nabyć umiejętności negocjowania ukierunkowanego na zachowanie pokoju światowego.

Niezrozumiałe jest przytaczanie za W. Welschem ogólników, cytowanie bez interpretacji pewnych sformułowań, bez odwołania się wieloletnich analiz i badań z zakresu edukacji międzykulturowej, prowadzonych chociażby w ramach wskazywanej wyżej Federacji Społecznych Zespołów Badań Kultury i Oświaty Pogranicza. Niezrozumiałe jest wskazywanie za Welschem, że międzykulturowość, podobnie jak wielokulturowość, wychodzi od tradycyjnego, bliskiego Herderowskiemu ujęciu kultury jako całości. Fenomen miedzy, pomiędzy, granicy i pograni- 
cza, efekt pogranicza czy człowiek pogranicza funkcjonują w naszych badaniach już od trzydziestu lat i żyją niezależnie od idei „trans”. Stąd nie traktowałbym tego jako gruntu do powołania koncepcji transkulturowej. Postrzegam to zupełnie odwrotnie, gdyż sam Welsch stwierdza, że już tradycyjne kultury nosiły znamiona mieszanych, zresztą nie mogło być inaczej. Jaką więc tożsamości transkuturową Autor ma na myśli, o jakie wytwarzanie nowej różnorodności mu chodzi, dlaczego przypisuje transkulturowości mozaiki międzykulturowe, określając je transkulturowymi. Wychodzenie poza było, jest i będzie, istotą zaś z pedagogicznego punktu widzenia jest to, z jakimi postawami wobec własnej kultury wychodzimy poza nią, jakie potrzeby ukierunkowują nas do wychodzenia poza granice własnej kultury, co może powodować rezygnację z własnego dziedzictwa kulturowego, jak kształtują się tożsamości międzykulturowe, hybrydowe, realizowanie się w dwóch kulturach. Te problemy podejmowaliśmy i podejmujemy w licznych ośrodkach akademickich zajmujących się edukacją międzykulturową.

Zapoznając się z pracą, niejednokrotnie odnosiłem wrażenie, że Autor sam sobie przeczy. Na przykład zakłada transkulturowe procesy wymiany, ale nie ukazuje ich w kontekście badanych Romów. Stwierdza, że transkulturowość wytwarza koegzystencję, a nie walkę, ponadto ukazuje w pracy ustawiczną walkę dominującej grupy z mniejszością romską, używając nawet określenia „ludzie transkulturowi” czy „mozaiki transkulturowe”. Wszystko przypisuje zbawiennej „trans”, nawet rozwiązanie dylematu pomiędzy partykularyzmem a homogenicznością. Jestem jednak przekonany, znając wyniki wielu badań w tym zakresie, że Romowie funkcjonują na pograniczu dwóch światów, dysponują bogatymi zasobami kulturowymi. Z jednej strony charakteryzują się kulturową hermetycznością, kultywują tradycyjne wartości, zasady, wzorce, a z drugiej wybierają z innej kultury to, co sprzyja ich międzykulturowemu funkcjonowaniu. Dobrze oddaje to cytat, którym Autor posługuje się w podrozdziale Próba transkulturowej interpretacji dokumentów oraz stanu badań dotyczq̨cych rzeczywistości społecznej Romów w Małopolsce. Odbieram go jako szczególnie istotny dla międzykulturowości. „Zachowamy swoją tożsamość. Pozostaniemy Romami, jednak obok tradycji uznamy reguły nowoczesności” (s. 84).

Chciałbym zauważyć i podkreślić, że w edukacji międzykulturowej różnicę i inność traktowaliśmy i traktujemy jako kapitał kulturowy, kapitał, którym człowiek dysponuje, z którego może wybierać. Zadaniem tej edukacji jest uświadomienie bogactwa i możliwości wyboru, uświadomienie tego daru i mocy tożsamościowej poprzez niwelowanie lęków i odczuwanego stygmatu, doprowadzenie do świadomego i odpowiedzialnego wyboru z kultury odziedziczonej i kultury kraju, którego jest się obywatelem. 
W ostatniej, czwartej części pracy, zatytułowanej Transkulturowa analiza rzeczywistości społecznej andrychowskich Romów zaprezentowano wyniki analiz treści przekazów medialnych dotyczących rzeczywistości społecznej andrychowskich Romów, uzupełniając je autorskimi notatkami terenowymi, które powstały w trakcie obserwacji uczestniczącej. Tu wysoko oceniam problem roli badacza w procesie badawczym, zaprezentowaną autoanalizę etnograficzną badacza. Jeżeli za dyskusyjne uznaję przyjęcie koncepcji trenskulturowości w analizie społecznej rzeczywistości andrychowskich Romów, to z uznaniem przyjmuję założenia metodologiczne, interakcję Autora badań z terenem, funkcją pełnomocnika burmistrza ds. mniejszości narodowych i etnicznych, aktywność i uznanie w lokalnej społeczności romskiej. Badania terenowe, które zostały przeprowadzone i przedstawione w pracy, zasługują moim zdaniem, na wyróżnienie.

Autor, analizując treści przekazów medialnych, łączył je z obserwacją uczestniczącej i w efekcie wyróżnił pięć etapów-cykli, które dotyczyły historii osiedlenia Romów w Andrychowie, powstawania i rozwiązywania konfliktów, kończąc na czasach współczesnych. Ostatni etap to etnograficzna autoanaliza badacza. Jak wyżej wskazywałem, nie jestem przekonany do koncepcji transkulturowości i przedstawiany przez Autora proces transkulturowy społeczności romskiej w Andrychowie odbieram i interpretowałbym w kontekście teorii akulturacji, założeń międzykulturowości i „efektu pogranicza”. Faktem jest, że ustawowy nakaz przymusowego osiedlenia spowodował zmianę stylu życia, przemiany tożsamościowe, poszukiwanie nowych form zarobkowania, włączenie w instytucjonalną edukację, ewolucję w kulturze artystycznej, zrzeszaniu się itp. Stąd niezbyt istotne jest, jaką koncepcję obierzemy do zaprezentowania procesu zmian zachodzących w społeczności Romów z Andrychowa. Istotne jest, jak ta teoria-koncepcja oświetla całą gamę wielorakich i zróżnicowanych danych. Jaką byśmy nie zastosowali, to kontynuowanie przez Romów tradycyjnego stylu życia i funkcjonujące stereotypy powodowały wiele konfliktów, narastania uprzedzeń, postaw dyskryminacyjnych, marginalizujących, separujących itp.

Problemem szczególnie istotnym była i ciągle jest kwestia edukacji dzieci romskich, obowiązku szkolnego, świadomości jej znaczenia w rozwoju człowieka. Autor zwraca uwagę na działania mające zintensyfikować proces edukacyjny wśród Romów i zauważa efekty w tym zakresie. Wskazuje na zjawisko zmian w folklorze romskim, dynamikę zapożyczeń i powstawanie odmiennych form w romskiej kulturze artystycznej. Ma także miejsce dostosowywanie romskich struktur organizacyjnych, stowarzyszeń do oczekiwań władz lokalnych, wpisywanie się w panoramę lokalnych organizacji pozarządowych w celu uzyskania dotacji na prowadzenie określonej działalności. Inkluzyjna polityka władz lokalnych, jako 
istotny element w przedstawianym przez Jacka Bylicę procesie transkulturowym, spowodowała, „iż autor zajął pozycję "pomiędzy« władzą lokalną a Romami, zostając obdarzony zaufaniem obydwu stron. Stworzyło to naturalna sytuację dialogu trnaskulturowego, w owym czasie określanego mianem »międzykulturowego«" (s. 131).

Zwracam na powyższe zdanie uwagę, gdyż w całej pracy zauważam, że to, co określano wcześniej jako międzykulturowe, Autor określa mianem transkulturowego, traktując to jako novum. W niektórych miejscach Autor podejmuje próby tłumaczenia się z tej zamiany pojęć, wskazując na przykład, że przyjęta strategia gminy na rzecz społeczności romskiej, jej zapis o interakcji kultur, przenikaniu się i wynikającym z tego rozwoju sugerują raczej transkulturowy charakter prowadzonych działań. Uważam, że nic nie sugeruje, a działania są jednoznacznie interkulturowe. Zwracam na to uwagę, gdyż odbieram to jako ignorowanie i podważanie zasadności działań interkulturowych (międzykulturowych) i sztuczne wprowadzanie pojęcia, które immanentnie jest związane z interkulturowością, otwartością na dialog.

Nie jest ważne, czy przedstawiany w cyklu drugim wybuch konfliktu określimy transkulturowym (Autor określił go otwartym konfliktem transkulturowym) czy kulturowym, międzykulturowym, gdyż jego istotą jest klasyfikowanie osób nie w kontekście obywatelstwa a przynależności do grupy mniejszościowej lub większościowej, w tym przypadku romskiej i polskiej. Cokolwiek się dzieje, to następuje kategoryzacja w kontekście swojskości i obcości oraz nawoływanie do obrony swojej grupy. Tak było i w tym przypadku. Osoby, które bezpośrednio dokonały wykroczeń (wymuszanie, pobicie), automatycznie postrzegano nie jako mieszkańców miasta Andrychowa, a jako reprezentantów mniejszości lub większości w kontekście etnicznym. Powstał, jak wskazuje Autor, „antyromski potencjał” , kumulowanie się nastojów antyromskich w sieci. „Jedna z osób, która w komentarzach nie zgadzała się z mową nienawiści, określeniami wulgaryzmami, została odsądzona od czci i wiary, nazwana nie-Polakiem, »mieszańcem«, a także wulgarnie wezwana do opuszczenia miasta” (s. 136). Można powiedzieć, że konfliktowe nastroje społeczne spowodowały uruchomienie wirusa zatruwającego umysł, racjonalne myślenie, w połączeniu z całą gamą negatywnych emocji. Wzrosło poczucie zagrożenia Romów, którzy obawiali się wychodzenia z domów i mieszkań. Zwracono uwagę, że żyjemy obok siebie, a nie ze sobą, a skrajnie prawicowe grupy wzniecają nienawiść. Na spotkaniu Młodzieży Wszechpolskiej określono Romów „kryminogenną mniejszością etniczną”, oczekując od burmistrza ich eksmisji.

Analizując treści prezentowane przez Bylicę dotyczące wybuchu, eskalacji konfliktu i prób jego harmonizacji, przypomniałem sobie ważne w tym kontekście 
powiedzenie Władysława Bartoszewskiego - ,jak nie wiemy, jak się zachować, to warto być przyzwoitym”. Stąd ważne były apele o rozmowy w kategorii prawnej, nie etnicznej, działania w zakresie edukacji i promowania tolerancji. W efekcie jednak przedstawiono plan relokacji Romów z centrum miasta, gdzie zostali osiedleni w latach 60. poprzedniego wieku. Wskazywano na nieskuteczną politykę asymilacyjną, nierozwiązany największy problem społeczny, co spowodowało zawiązanie komitetu „Bezpieczne Miasto”. Zarówno w romskiej, jak i polskiej narracji miało miejsce rozróżnienie na „my” i „oni”, jako typowy sposób percepcji lokalnej społeczności. Jak wskazuje Autor (s. 141) „Ten dychotomiczny podział stoi w opozycji do retoryki transkulturowej”, a więc można twierdzić, że Autor skorzystał z koncepcji mało przydatnej do realizacji własnego projektu badawczego. Zresztą Autor sam zauważa, że koncepcja transkuturowości nie za bardzo odpowiada prezentowanym cyklom. Uważam, że nie została ukształtowana, kultura pogranicza interakcyjnego i świadomościowego, ani kultura postrzegania człowieka jako współmieszkańca miasta, obywatela funkcjonującego w dwóch kulturach, reprezentującego tożsamość odziedziczoną i nabywaną tożsamość społeczno-kuturową. Dylematy związane z powyższym i wypracowaną w tym kontekście Teorię Wielozakresowej i Wielowymiarowej Tożsamości przedstawiam w pracy Etnopedagogika w kontekście wielokulturowości i ustawicznie kształtujq̨cej się tożsamości.

Wydaje mi się, że Autor wartościowej poznawczo pracy o andrychowskich Romach nie zauważył istotnych problemów, szczególnie ważnych z pedagogicznego punktu widzenia: czy społeczność mniejszościowa i nasze społeczeństwo większościowe pozwala na swobodne wychodzenie poza własną kulturę, dlaczego ustawicznie pojawiają się podziały na „my” i „oni”, czy w człowieku, niezależnie od jego przynależności etnicznej, nie drzemie potężny potencjał ksenofobii, lęku i wrogości wobec innych, czy możliwe jest zniwelowanie tego potencjału, zmiana perspektywy postrzegania się i wartościowania?

Sądzę, że koncepcja transkulturowości przedstawiona i interpretowana przez Jacka Bylicę nie będzie miała wartości, dopóki Polacy będą postrzegać Romów stereotypowo i negatywnie (posiadają naturalne predyspozycje do popełniania przestępstw, są gorzej wykształcenie, nieodpowiedzialni, zagrożeni bezrobociem, wykluczeniem społecznym, żyją w izolacji itp.). Postrzegamy ich marginalizując i wyłączając, co ukazał Autor pracy, a oni nasz świat postrzegają jako obcy i wrogi, a więc dostosowują się zewnętrznie do jego wymogów. Z analizy niniejszej pracy wynika więc potrzeba pracy edukacyjnej od podstaw, praca nad kształtowaniem kultury pogranicza tożsamościowego, aby realizować się jednocześnie w trzech 
zakresach (dziedzictwie przodków, rolach obywatelskich i własnych potrzebach społeczno-kulturowych).

Autor ma rację, wskazując na cykliczność konfliktu, czyli że nic się nie zmienia mimo upływu lat w świadomości obywateli. Wartościowa jest interpretacja tego konfliktu jako repliki konfliktu polsko-żydowskiego, który miał miejsce w Andrychowie po odzyskaniu przez Polskę niepodległości. Podział na swój i obcy ujawnia się natychmiast w sytuacji jakiegokolwiek konfliktu. Uważam, że jesteśmy jakby wpisani w model „dezintegracji pozytywnej”, tak jak każdy z nas jest zanurzony w tożsamości odziedziczonej. Mamy i będziemy mieli do czynienia z różnymi prądami, które będą się ścierały, nakładały na siebie, będą „falowały” - idee emancypacji versus dominacji, paradygmatu dialogu i współistnienia versus walki i zwalczania się. Mamy do czynienia z ruchliwością horyzontalną i wertykalną, wzrostem anonimowości, problemem niechęci do stałych i długotrwałych zobowiązań, zmiennością idei, niechęcią długotrwałego przywiązania do idei i do ludzi, unikania stałego zdefiniowania itp. Wiemy, jak wiele jest i może być społeczno-kulturowych identyfikacji, analizujemy dylematy lojalności w kontekście przynależności i aspirowania do przynależności. Wskazujemy na fragmentaryzację tożsamości, niezdefiniowaną, niegotową, wielopłaszczyznową, kontekstualną, z gorsetem aksjologii partyjnej czy administracyjnej itp.

Cykl czwarty zaprezentowany przez Bylicę jako Transkulturowa harmonizacja konfliktu w latach 2015-2018 określiłbym jako Ku kulturze życia pogranicznego czy życiu na pograniczu kultur. Uważam, że odmienne kulturowo grupy są skazane na ustawiczną naukę i kształtowanie kultury współżycia, wobec czego winny zorganizować edukację w zakresie przedstawienia historii i losów odmiennych kulturowo grup oraz wskazać na możliwości wspólnego działania obywatelskiego na rzecz rozwoju swojego miasta. Tak się stało w tym przypadku, analizując historię rozwoju miasta, tkactwa, przemysłu bawełnianego, wkład Żydów w rozwój miasta. Wskazanie, że Andrychów był miastem dwóch kultur, polskiej i żydowskiej, które przenikały się do czasów II wojny świtowej. W latach sześćdziesiątych pojawili się Romowie. Żydzi mieli duży wkład w rozwój andrychowskiego przemysłu w odróżnieniu od Romów, ludzi bez etosu pracy, stąd problemy.

W cyklu piątym zatytułowanym Etnograficzna autoanaliza badacza Autor zwraca uwagę, że badacz stoi nieco na uboczu, na pograniczu dwóch światów. Sądzę, że nie tylko badacz, ale każdy z mieszkańców i z tej perspektywy można byłoby interpretować kulturę pogranicza stykowego w kontekście pewnych elementów kultury, przejściowego, interakcyjnego i świadomościowego ukierunkowanego na kształtowanie wspólnot ponad różnicami etnicznymi. 
W dyskusji wyników i we wnioskach z badań Jacek Bylica zwraca uwagę na to, że Romowie przekraczali własne granice kulturowe. Można zapytać - czy mieli inne możliwości? Musieli przekraczać mniej lub bardziej świadomie, byli zmuszeni to czynić w kontekście funkcjonowania w rolach społecznych, będąc mieszkańcami miasta. Problemem było i jest to, w jakim zakresie funkcjonowali i uznawali kulturę po przekroczeniu granicy, co adoptowali do własnego systemu kulturowego, czy i co modyfikowali w tym systemie, czy miała miejsce hybrydyzacja lub reakcja akulturacyjna, czy dekompozycja, w związku z włączeniem jednych elementów, modyfikacją czy odrzuceniem innych itp. Istotna jest reakcja reprezentantów grupy większościowej, zachodzące interakcje i reakcja oraz to, czy reprezentanci kultury większościowej wychodzili im naprzeciw, podejmowali wspólne działania na rzecz kształtować kultury pogranicza.

Autor wskazuje, że musimy nauczyć się konstruktywnie kooperować z „Innymi”, zamiast wykluczać ich z życia społecznego (s. 172). Zgadzam się z tym wskazaniem i jestem przekonany, że tym się kieruje edukacja międzykulturowa. Stąd nie rozumiem wskazania (s. 173): „Być może nadszedł czas na budowanie tożsamości transkulturowej dla całej wspólnoty lokalnej”. Nie wiem, jak Autor rozumie tożsamość transkuturową, gdyż o tym nie pisze. Problem tożsamości jest problemem szczególnie złożonym. Traktując ją jako proces w obecnych warunkach wielokulturowego świata, zawsze wychodzimy poza swoją kulturę, zawsze przekraczamy granice. Stąd zgadzam się z Autorem, że nie tempo, ale otwartość na obopólne wpływy jest istotna na budowanie tożsamości. Podobnie nie rozumiem podsumowania Autora, gdzie Jego zdaniem „wojna polsko-romska” przyniosła pozytywne transkulturowe rozstrzygnięcia, że transkulturowość rodzi się w wysokiej amplitudzie konfliktu będącego konsekwencją transkuturowego napięcia.

Podsumowując uważam, że Autor pracy Cygańska rapsodia... winien wyraźnie oddzielić problem transkulturowego paradygmatu badań naukowych, problem innowacyjnych sposobów rozwijania u studentów krytycznego myślenia, efektywnego wykorzystywania intelektualnego kapitału studentów z innych kultur od analizowanej rzeczywistości społeczno-kulturowej Romów andrychowskich. To są różne obszary badań i analiz, niby powiązane z sobą, ale nie pozostające w dynamicznych zależnościach. Może więc mieć miejsce - i sądzę, że ma - w jednym przypadku progres, w drugim stagnacja, nawet regres. Taka jest natura badań naukowych, procesu edukacji akademickiej, inna może być specyfika kultury romskiej, jej przekazu, kultywowania, losów i doświadczeń przedstawicieli tej grupy etnicznej, nieposiadającej odniesień do własnego państwa. To, co Autor 
pisze, wyraźnie wskazuje na funkcjonowanie międzykulturowe, na przykład „[...] poza adaptacyjną fasadą Romowie zwykle byli wierni wartościom wynikającym z Romanipen, tj. niepisanego kodeksu regulującego całość postępowania (w tym kwestię ubioru)” (s. 55). Korzystając z moich wieloletnich doświadczeń, analizowałbym funkcjonowanie Romów w naszym kraju, czerpiąc z innych teorii, czy koncepcji na co próbowałem wskazać wyżej. Szanuję wybór i doceniam próby operowania różnymi określeniami transkulturowości, jednak moim zdaniem nie odpowiadają one przedstawionemu projektowi badawczemu.

\section{Bibliografia}

Bylica, J. (2019). Cygańska rapsodia. Transkulturowe studium rzeczywistości społecznej andrychowskich Romów - konteksty pedagogiczne. Kraków: Wydawnictwo Uniwersytetu Jagiellońskiego.

Kopczyński, M. (2010). Wstęp. W: M. Kopczyński, W. Rygielski (red.), Pod wspólnym niebem. Narody Dawnej Rzeczypospolitej (s. 7-21). Warszawa: Muzeum Historii Polski, Bellona.

Nikitorowicz J. (1995). Pogranicze - Tożsamość - Edukacja międzykulturowa. Białystok: „Trans Humana”.

Witkowski, L. (1995). Ambiwalencje tożsamości z pogranicza kulturowego. W: M.M. Urlińska (red.) Edukacja a tożsamość etniczna. Materiały z konferencji naukowej w Rabce. Studia kulturowe i edukacyjne (s. 13). Toruń: Wydawnictwo UMK. 